\title{
Cold start emissions from a gasoline engine in RDE tests at different ambient temperatures
}

The implementation of the 3rd package of the RDE test procedure has extended the test method by considering emissions from a cold start period into the total exhaust emissions from a vehicle. The article presents the research results of exhaust emissions of a vehicle equipped with a gasoline engine. The tests were carried out at two different ambient temperatures, in line with the requirements of the $R D E$ test procedure for passenger cars, meeting the Euro 6d-Temp emissions standard. The obtained results were analyzed, i.e. there were compared the engine and vehicle operating parameters and the values of road exhaust emissions during the cold start at two different ambient temperatures. The summary presents the shares of the cold start phase for each exhaust emission compound in the urban part of the test and the entire RDE test, depending on the ambient temperature $\left(8^{\circ} \mathrm{C}\right.$ and $\left.25^{\circ} \mathrm{C}\right)$.

Key words: cold start, RDE test, exhaust emissions, ambient temperature, gasoline engine

\section{Introduction}

Road transport is still considered the most important source of air pollution. Scientific research [16] indicates that the emission of harmful exhaust compounds has a negative impact not only on air quality but also on human health. This phenomenon is particularly visible in urban agglomerations. One of the European Union's tasks, set off for the coming years, is to continue and even intensify work on improving air quality. The European Commission's assumption is to achieve climate neutrality. However, to gain this, the level of air pollution should first be gradually reduced. To this end, among other, increasingly restrictive legal acts concerning vehicle exhaust emissions are introduced [2-6]. Meeting these requirements is not easy, so it is necessary to use more and more advanced exhaust after-treatment systems.

In recent years, many research papers on cold start emissions have been published (i.a. [13, 17, 19, 24, 30]). The need to take into account emissions from the cold start phase has been noticed not only in Europe but also worldwide. The authors of the articles $[18,26]$ pointed out the importance of the cold start issue as well as the necessity of further improvement of exhaust after-treatment systems. Whereas, the authors of the publications $[8,10,11]$ suggested that $\mathrm{NO}_{\mathrm{x}}$ emission should be an issue addressed in subsequent updates of EU regulations. According to the authors of the publication [8], the $\mathrm{NO}_{\mathrm{x}}$ emissions from vehicles, equipped with a gasoline engine, are increasingly higher and consequently, particularly important in the context of urban air quality. The authors also pay attention to the value of the ambient temperature at which the RDE test is performed.

The authors of the articles [31,33] came to the same conclusions. They determined the impact of different ambient temperatures $\left(-7^{\circ} \mathrm{C}\right.$ and $\left.23^{\circ} \mathrm{C}\right)$ on the emission results of vehicles equipped with compression and spark-ignition engines. The aim of the test was to verify the results according to Euro 6 emissions standard and check if the exhaust emissions in the WLTC test increase during the cold season in comparison to higher ambient temperatures $[7,8]$. The authors of this article noticed the need to develop a new and independent procedure allowing verification of the emissions level at low ambient temperatures.

\section{RDE test conditions}

Although the RDE test is performed under real traffic conditions, it is highly formalized. The requirements concern not only the vehicle conditioning for the test but also the provision of research conditions [1, 12, 14, 20-23]. According to $[27,28]$, this is necessary for the proper performance of the test and further analysis of the results obtained. The main requirements to be met during the test are shown in Fig. 1. Due to the vehicle speed, the test route is divided into three parts: urban, rural and motorway conditions. The test drive is carried out continuously, but there are a few exceptions [9]. The rural drive section can be interrupted by short periods of urban driving if urban areas are on the route. Driving on the motorway can interrupt short driving periods in urban or rural areas. The duration of the test is within the acceptable range, i.e. between 90 min and $120 \mathrm{~min}$

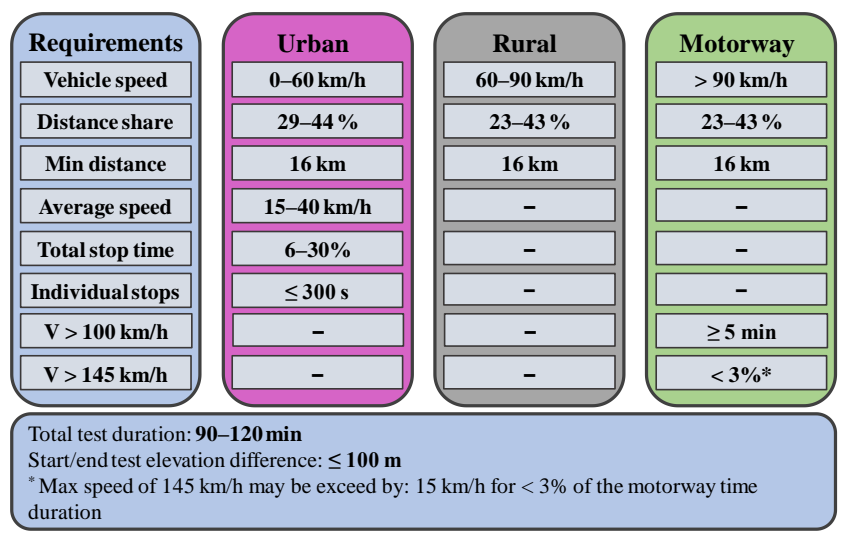

Fig. 1. The RDE test requirements [25-28]

Package 3 [27] of the RDE test procedure has introduced primarily the inclusion of cold-start period emissions in the entire RDE test. The definition of cold start is as follows - the period from the first start of a combustion engine until the point when the combustion engine has run cumulative for $5 \mathrm{~min}$. The cold start period ends once the coolant temperature has reached $70^{\circ} \mathrm{C}$ for the first time but 
no later than after $5 \mathrm{~min}$ from the initial engine start. The main requirements for a cold start are listed in Fig. 2.

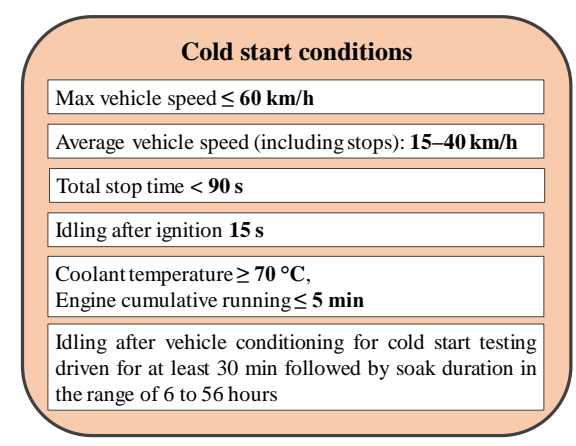

Fig. 2. Cold start requirements [32]

The $4^{\text {th }}[28]$ package of the RDE test procedure modified the calculation of total exhaust emissions but also specified the exhaust emissions obtained in the urban part (compared to total emissions in the test). This article aims to determine the shares of specific exhaust compounds during the cold start phase and in the entire test, depending on the ambient temperature $\left(8^{\circ} \mathrm{C}\right.$ and $\left.25^{\circ} \mathrm{C}\right)$.

\section{Research methodology}

\subsection{Research object}

One of the popular midsize passenger car class was used for testing. The vehicle was equipped with a gasoline engine that met the Euro 6d-Temp emissions norm. The exhaust after-treatment system consists of a 3-way catalytic converter and a particulate filter. Details of the vehicle used are shown in Table 1.

Table 1. Characteristics of the passenger car used in testing

\begin{tabular}{|l|c|}
\hline Curb weight & $1450 \mathrm{~kg}$ \\
\hline Engine type & $\begin{array}{c}\text { turbocharged gasoline engine } \\
\text { with direct injection }\end{array}$ \\
\hline Displacement volume & $1.6 \mathrm{dm}^{3}$ \\
\hline Maximum power & $130 \mathrm{~kW}$ \\
\hline Emission standards & Euro $6 \mathrm{~d}-\mathrm{Temp}$ \\
\hline The after-treatment system & $\begin{array}{c}\text { three-way catalytic converter } \\
\text { with a particulate filter }\end{array}$ \\
\hline
\end{tabular}

\subsection{Test route and exhaust emission measurements}

The test route has been designated in accordance with RDE requirements and divided into 3 sections; urban, rural and motorway (Fig. 3). The driving distances, shares of the individual portion of the test have been chosen so that they meet the requirements described in [26].

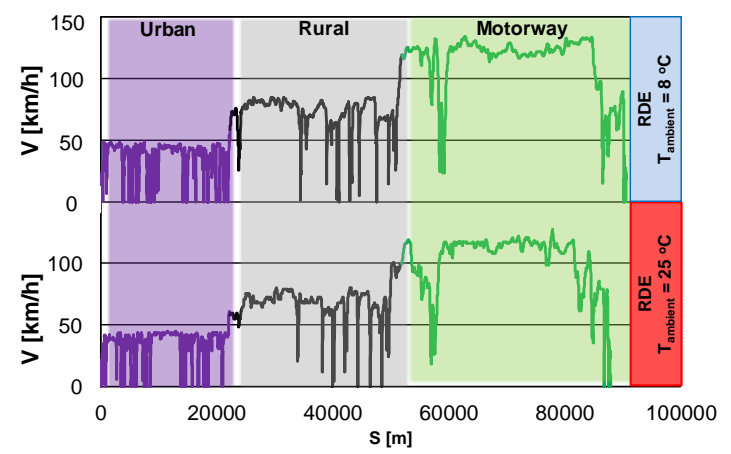

Fig. 3. Vehicle speed profiles in both RDE test drives
The authors carried out two test drives on the same research route in the city of Poznan and its surroundings by the same driver. Measurements were conducted in two different ambient temperatures $\left(8^{\circ} \mathrm{C}\right.$ and $\left.25^{\circ} \mathrm{C}\right)$. For measuring the concentration of exhaust compounds, a PEMS apparatus was used. Besides, the GPS signal was recorded at a frequency of $1 \mathrm{~Hz}$ during testing. The research equipment used was compliant with the European Union requirements concerning the measurement of harmful exhaust compounds from passenger cars under real driving conditions.

\section{The analysis of recorded parameters}

\subsection{Engine operating parameters of the vehicle}

The first stage of the analysis was to validate the performance of road tests with the requirements of the RDE test procedure. All parameters were verified by appropriate procedures and no deviations from the required values were found. However, in the case of this article the most important was to check the validity of the cold start emission parameters and the boundary conditions (these parameters were discussed in the next point).

Therefore, the analysis of vehicle speed during the cold start period has been made. It is required to start driving for a maximum of 15 seconds after starting the engine (Fig. 4). This condition was met in both cases and at the same time a similar character of the vehicle speed profiles in the first $300 \mathrm{~s}$ of the RDE test is shown. Slightly higher values of the maximum vehicle speed were recorded for the lower ambient temperature.

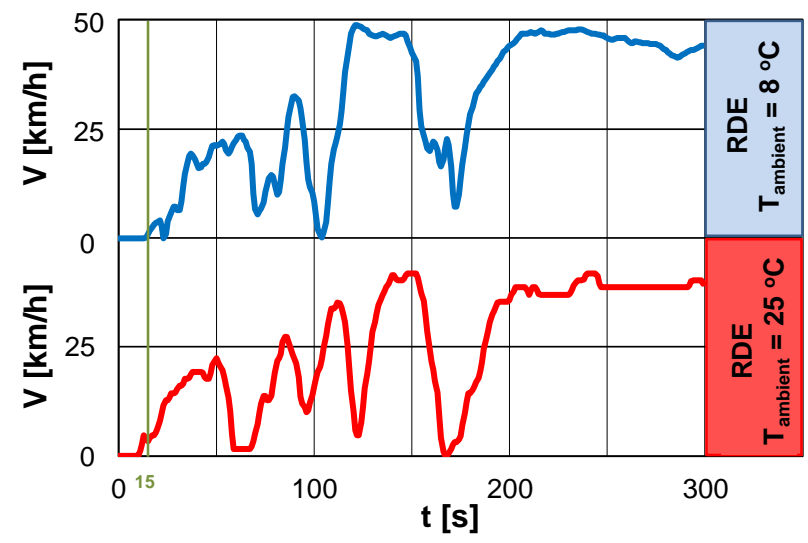

Fig. 4. Vehicle speed during the cold start phase at different ambient temperatures

The comparison of the coolant temperature in both cases also shown that the requirements of the RDE test procedure have been met, i.e. it did not exceed the value of $70^{\circ} \mathrm{C}$. For the cold start at the ambient temperature of $25^{\circ} \mathrm{C}, 300 \mathrm{~s}$ from the engine start, the coolant temperature achieved a value of $69^{\circ} \mathrm{C}$. For the ambient temperature of $8^{\circ} \mathrm{C}$, the coolant temperature was only $57^{\circ} \mathrm{C}$. Firstly, the initial coolant temperature difference of $17^{\circ} \mathrm{C}$ but after $300 \mathrm{~s}$ (since the engine was started) it decreased to $12^{\circ} \mathrm{C}$. Therefore, a greater coolant temperature gradient was found for lower ambient temperature (Fig. 5). 


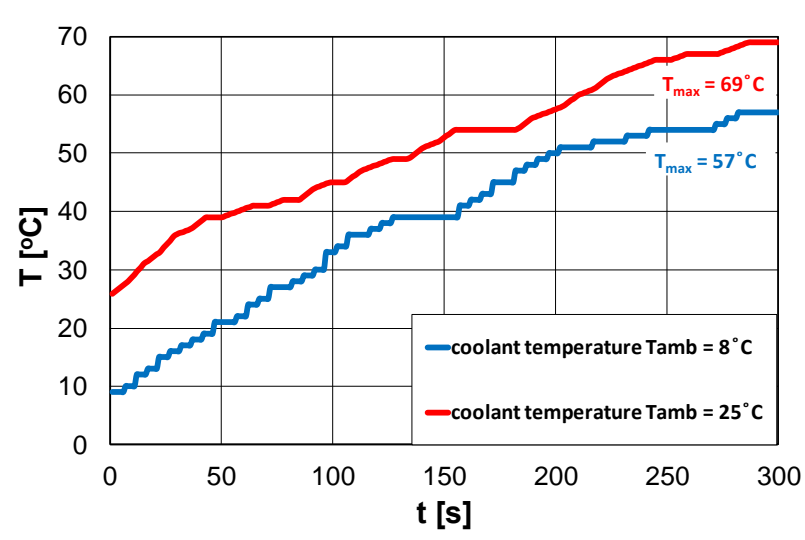

Fig. 5. The coolant temperature during the cold start phase at different ambient temperatures

A similar character of the changes was also observed during the analysis of exhaust temperature, measured at the end of the vehicle exhaust system. The difference for the measurement time $(\mathrm{t}=0 \mathrm{~s})$, amounting to about $12^{\circ} \mathrm{C}$, is compensated already after about $100 \mathrm{~s}$, where the exhaust temperature is around $30^{\circ} \mathrm{C}$. The further profile of exhaust temperature is very similar to each other, and the differences occurring in the period up to $300 \mathrm{~s}$ are very small (Fig. 6).

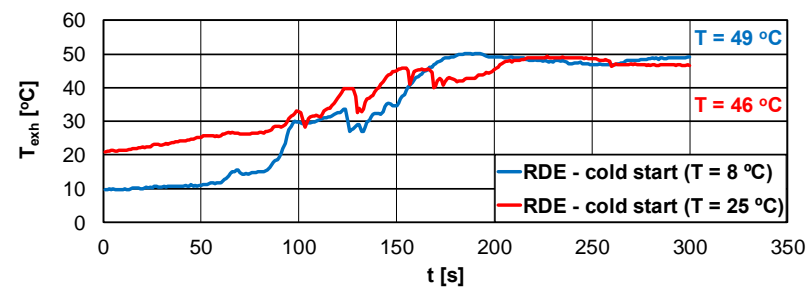

Fig. 6. The exhaust temperature during the cold start phase at different ambient temperatures

\subsection{Ecological parameters}

The recorded profile of emission intensity changes in the cold start period $(\mathrm{t}=0-300 \mathrm{~s})$ for two different ambient temperatures $\left(8^{\circ} \mathrm{C}\right.$ and $\left.25^{\circ} \mathrm{C}\right)$ are shown in Figs. $7-10$.

The carbon monoxide mass is almost 3 times higher at the ambient temperature of $8^{\circ} \mathrm{C}(3.47 \mathrm{~g})$ in comparison to the value of $25^{\circ} \mathrm{C}(1.21 \mathrm{~g})$. The average value of the emission intensity is $0.011 \mathrm{~g} / \mathrm{s}$ (at the ambient temperature of $8^{\circ} \mathrm{C}$ ) and $0.004 \mathrm{~g} / \mathrm{s}\left(\right.$ at $\left.25^{\circ} \mathrm{C}\right)$. For the cold start at the ambient temperature of $25^{\circ} \mathrm{C}$, the highest value of emissions intensity is $0.09 \mathrm{~g} / \mathrm{s}$. While for the temperature of $8^{\circ} \mathrm{C}$ this value is twice higher (Fig. 7).

The analysis of carbon dioxide emission intensity shows that during the cold start and warming the engine, the mass of this compound is about $16 \%$ higher at the ambient temperature of $8^{\circ} \mathrm{C}(687 \mathrm{~g})$ than at $25^{\circ} \mathrm{C}(592 \mathrm{~g})$. The average value of the emission intensity is $2.19 \mathrm{~g} / \mathrm{s}$ and $1.89 \mathrm{~g} / \mathrm{s}$, respectively. The fluctuations between the results of test drives were caused by the changes in the dynamic motion conditions. However, the average value of this parameter is not affected by the ambient temperature at which the cold engine started (Fig. 8).

The analysis of nitrogen oxides emission intensity shows that for this exhaust compound the relations are completely different than for the previous compounds. For the higher ambient temperature $\left(25^{\circ} \mathrm{C}\right)$ the main increase of nitrogen oxides intensity (up to $0.005 \mathrm{~g} / \mathrm{s}$ ) is observed at the first 50 seconds after the engine started. During the cold start phase, the mass of this compound is equal to $0.400 \mathrm{~g}$ and the average value of the emission intensity is $0.0293 \mathrm{~g} / \mathrm{s}$. In the case of lower ambient temperature $\left(8^{\circ} \mathrm{C}\right)$, the intensity of nitrogen oxides is about $11 \%$ higher than at $25^{\circ} \mathrm{C}$. For the value of $8^{\circ} \mathrm{C}$, the highest values of emission intensity are reached at the first $100 \mathrm{~s}$ and then they are being reduced (Fig. 9).

a)

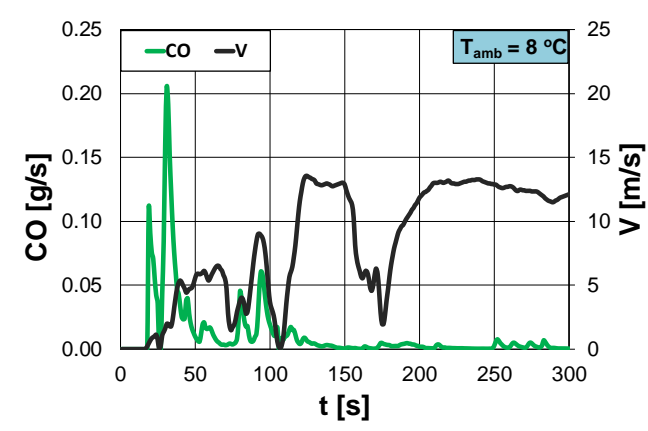

b)

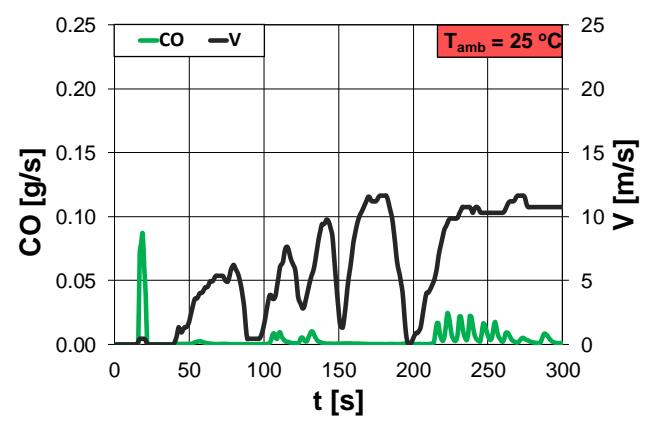

Fig. 7. Emission intensity of carbon monoxide and vehicle speed during cold start at ambient temperature of $8^{\circ} \mathrm{C}$ (a) and $25^{\circ} \mathrm{C}($ b)

a)

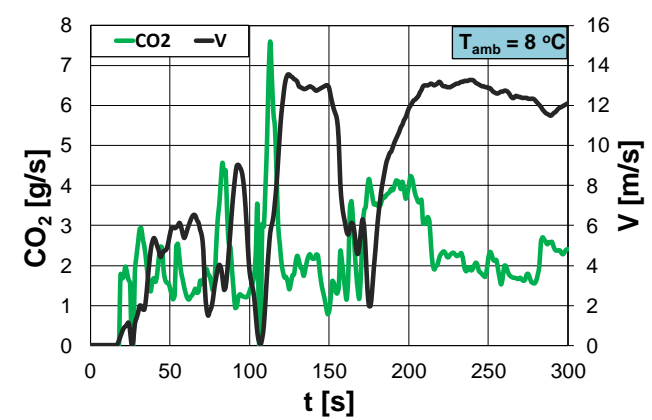

b)

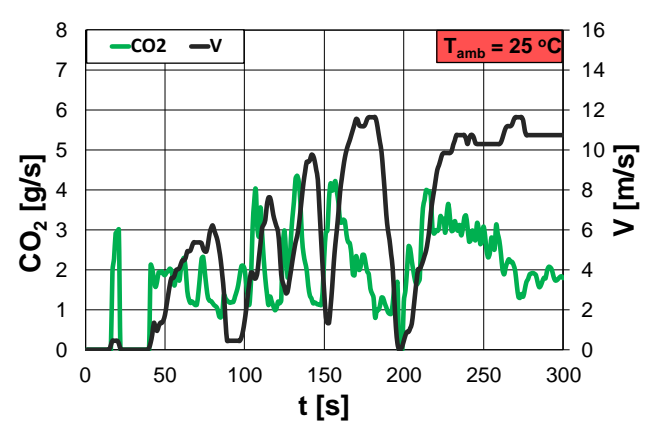

Fig. 8. Emission intensity of carbon monoxide and vehicle speed during cold start at ambient temperature of $8^{\circ} \mathrm{C}$ (a) and $25^{\circ} \mathrm{C}$ (b) 
Regarding the number of particulates at the ambient temperature of $25^{\circ} \mathrm{C}$, there is a peak (up to $1.45 \mathrm{E}+09$ ) in the first $40 \mathrm{~s}$ after the engine started. At the ambient temperature of $8^{\circ} \mathrm{C}$, this peak occurs earlier $(\mathrm{t}=30 \mathrm{~s})$ and reaches $1.20 \mathrm{E}+10$ (Fig. 10). The particles number, in the period of $300 \mathrm{~s}$ from starting, increased by almost 4 times during the reduction of temperature value from $25^{\circ} \mathrm{C}$ to $8^{\circ} \mathrm{C}(7.5 \mathrm{E}+10$ and $2.8 \mathrm{E}+11)$. The research results of emission intensity (Fig. 7) were used to determine the road emissions (converting the mass per unit of the road) during the cold start phase (lasting $300 \mathrm{~s}$ ).

a)

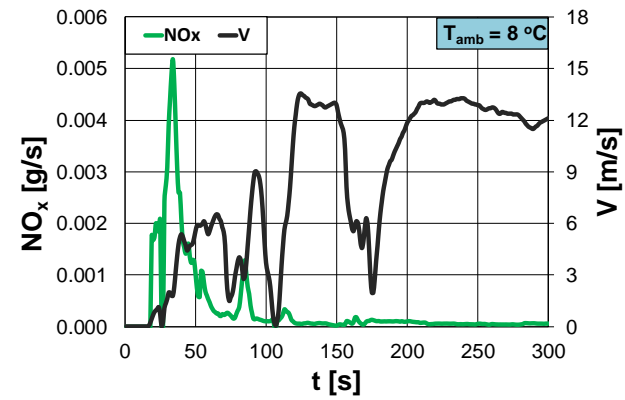

b)

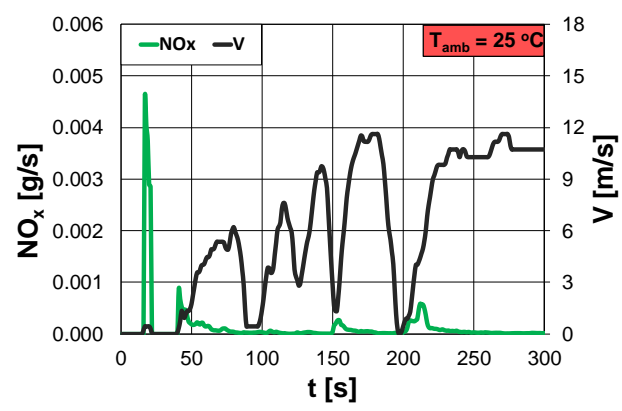

Fig. 9. Emission intensity of nitrogen oxides and vehicle speed during cold start at ambient temperature of $8^{\circ} \mathrm{C}$ (a) and $25^{\circ} \mathrm{C}$ (b)

a)

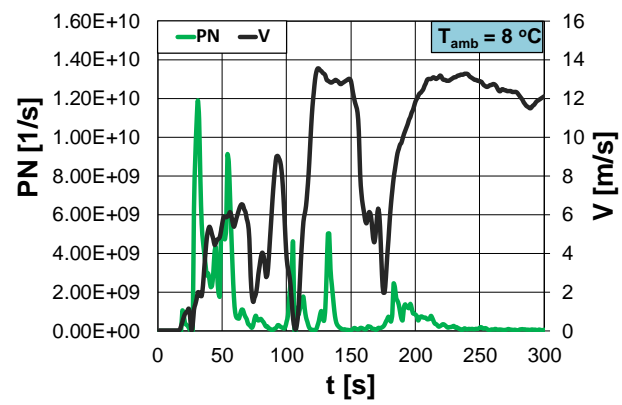

b)

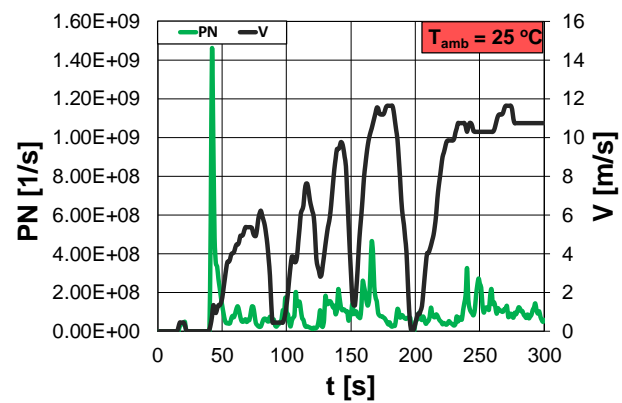

Fig. 10. Emission intensity of particle numbers and vehicle speed during cold start at ambient temperature of $8^{\circ} \mathrm{C}$ (a) and $25^{\circ} \mathrm{C}$ (b)
The reduction of the ambient temperature (from $25^{\circ} \mathrm{C}$ to $8^{\circ} \mathrm{C}$ ) during the cold start (in the considered period of $300 \mathrm{~s}$ ) results in (Fig. 11):

- an increase by $68 \%$ of $\mathrm{CO}$ road emissions,

- an increase by $15 \%$ of $\mathrm{CO}_{2}$ road emissions,

- a decrease by $50 \%$ of $\mathrm{NO}_{\mathrm{x}}$ road emissions,

- an increase by $47 \%$ of PN road emissions.

a)

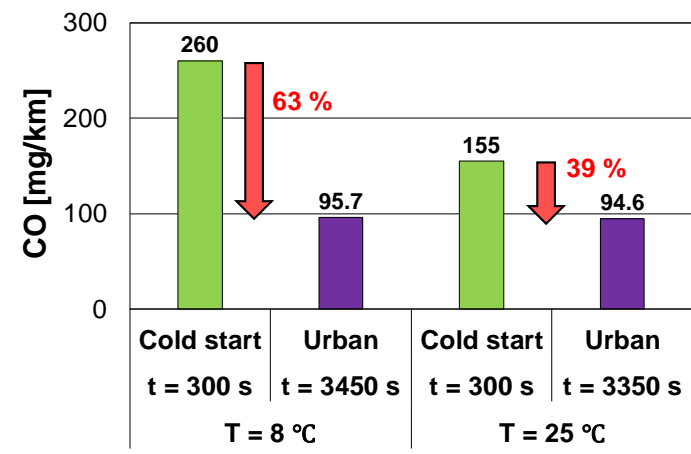

b)

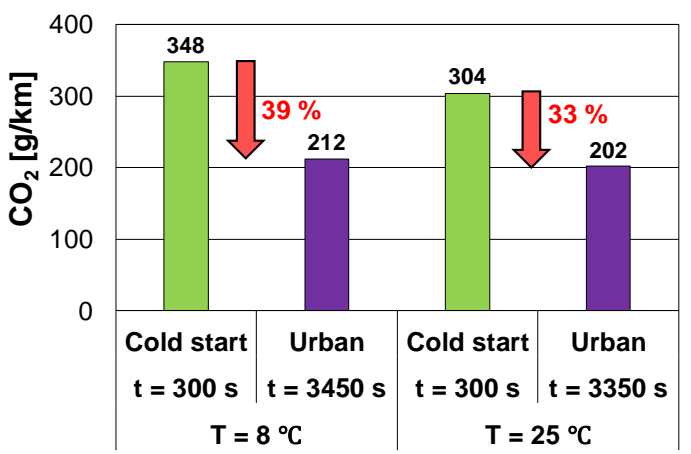

c)

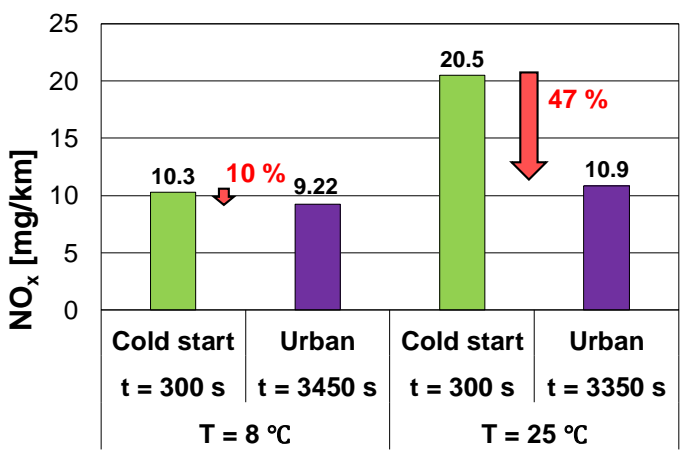

d)

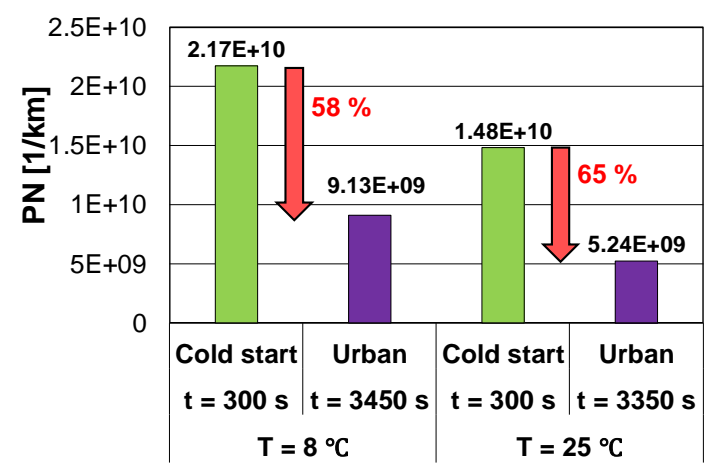

Fig. 11. Road emissions of $\mathrm{CO}(\mathrm{a}), \mathrm{CO}_{2}$ (b), $\mathrm{NO}_{\mathrm{x}}$ (c), $\mathrm{PN}(\mathrm{d})$ at two different ambient temperatures 
Comparing the cold start phase for different ambient temperatures in the urban part of the RDE test and in the entire RDE test are shown in Fig. 12 and 13. For the value of ambient temperature equal to $8^{\circ} \mathrm{C}$, the results are as follows:

1. The share of CO emissions during the cold start (300 s) in relation to the urban part of RDE test is $26.0 \%$; and in the relation to the entire RDE test it increases to $10.8 \%$.

2. The share of $\mathrm{CO}_{2}$ emissions during the cold start (300 s) in relation to the urban part of the RDE test is $11.6 \%$; and in the relation to the entire RDE test it decreases to $3.40 \%$.

3. The share of $\mathrm{NO}_{\mathrm{x}}$ emission during the cold start (300 s) in relation to the urban part of RDE test is $10.6 \%$; and in the relation to the entire RDE test it decreases to $2.92 \%$.

4. The share of PN emissions during the cold start (300 s) in relation to the urban part of RDE test is $22.7 \%$; and in the relation to the entire RDE test it decreases to $0.05 \%$.

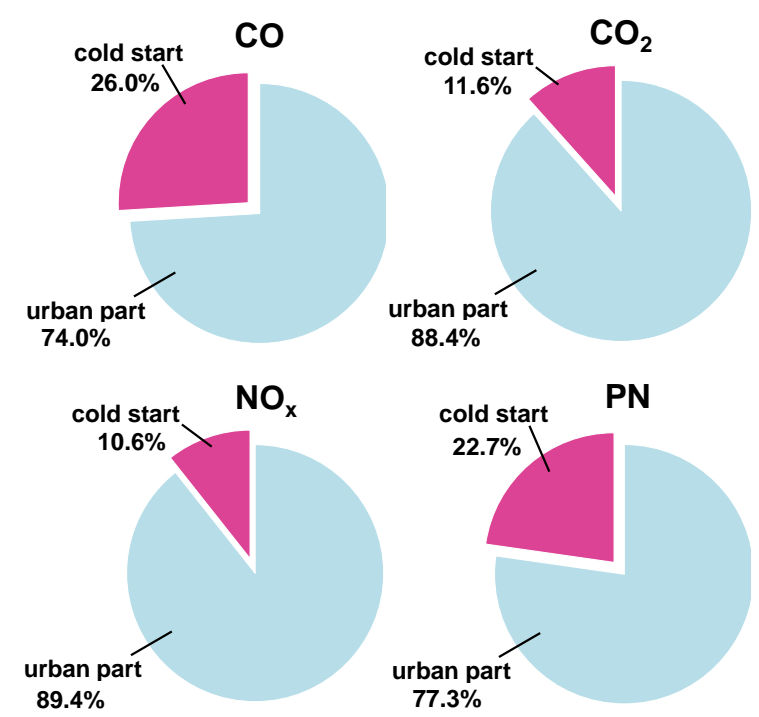

Fig. 12. Share of $\mathrm{CO}, \mathrm{CO}_{2}, \mathrm{NO}_{\mathrm{x}}$ and $\mathrm{PN}$ emissions in urban section during cold start at $8^{\circ} \mathrm{C}$
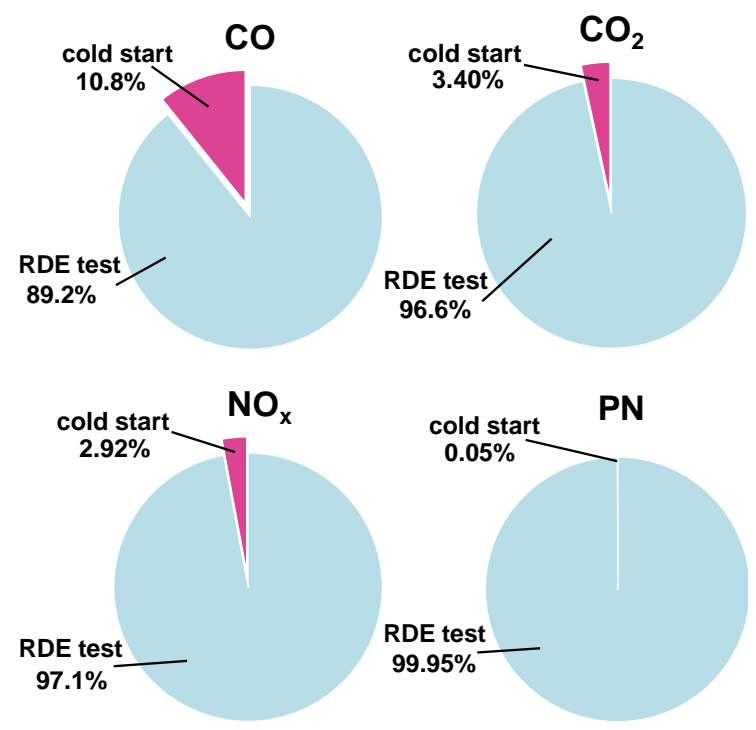

Fig. 13. Share of $\mathrm{CO}, \mathrm{CO}_{2}, \mathrm{NO}_{\mathrm{x}}$ and $\mathrm{PN}$ road emissions in the entire RDE test during cold start at $8^{\circ} \mathrm{C}$
In the case of the ambient temperature equals to $25^{\circ} \mathrm{C}$ the results are as follows (Fig. 14 and 15):

1. The share of $\mathrm{CO}$ emissions during the cold start $(300 \mathrm{~s})$ in relation to the urban part of RDE test is $10.7 \%$; and in the relation to the entire RDE test it decreases to $4.63 \%$.

2. The share of $\mathrm{CO}_{2}$ emissions during the cold start (300 s) in relation to the urban part of the RDE test is $9.80 \%$; and in the relation to the entire RDE test it decreases to $3.40 \%$.

3. The share of $\mathrm{NO}_{\mathrm{x}}$ emission during the cold start (300 s) in relation to the urban part of RDE test is $12.3 \%$; and in the relation to the entire RDE test it decreases to $3.42 \%$.

4. The share of PN emissions during the cold start (300 s) in relation to the urban part of RDE test is $18.4 \%$; and in the relation to the entire RDE test it decreases to $0.05 \%$.

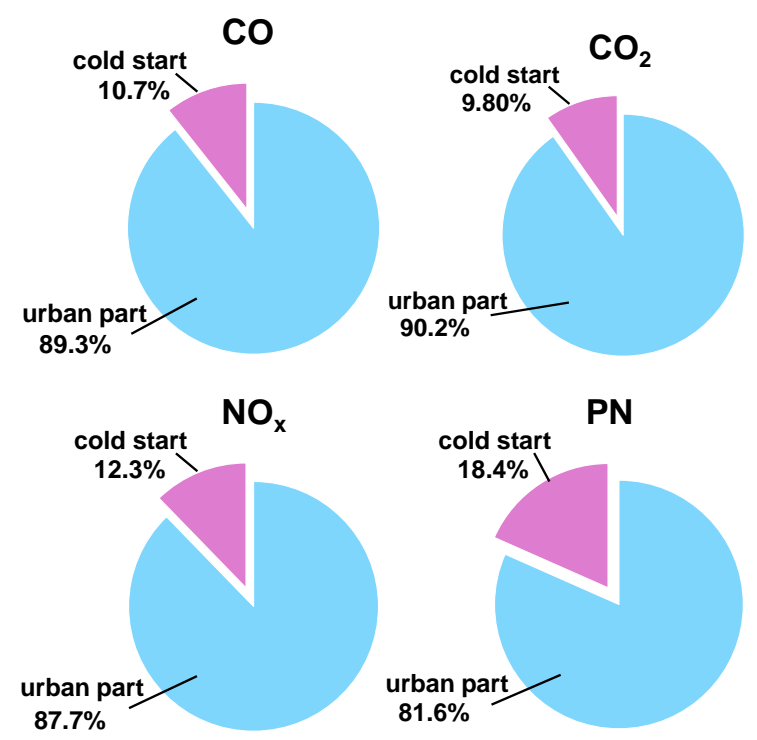

Fig. 14. Share of $\mathrm{CO}, \mathrm{CO}_{2}, \mathrm{NO}_{\mathrm{x}}$ and $\mathrm{PN}$ emissions in urban section during cold start at $25^{\circ} \mathrm{C}$

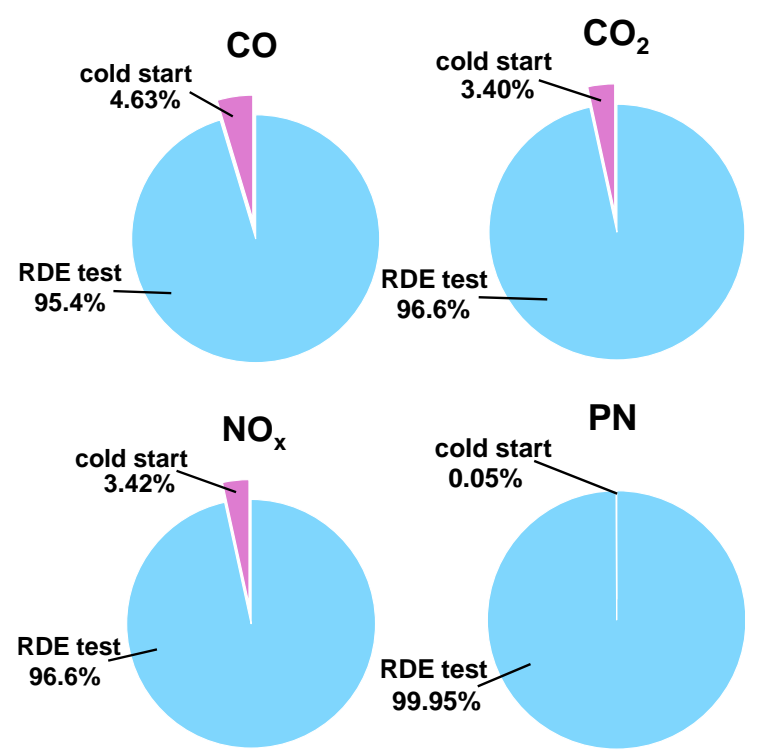

Fig. 15. Share of $\mathrm{CO}, \mathrm{CO}_{2}, \mathrm{NO}_{\mathrm{x}}$ and $\mathrm{PN}$ road emissions in the entire RDE test during cold start at $25^{\circ} \mathrm{C}$ 


\section{Summary and conclusions}

The RDE test procedure is still being developed and improved. Package 3 extended this road emission test by taking into account the emissions from cold start phase to the total value of exhaust emissions.

The article presents and discuss the research results on the impact of ambient temperature $\left(8^{\circ} \mathrm{C}\right.$ and $\left.25^{\circ} \mathrm{C}\right)$ during the cold start phase of the gasoline engine in emission road tests. The measurements were carried out in compliance with the latest legislative procedures applicable to passenger cars. After the analysis of the engine operating parameters, there were defined its ecological parameters (emission intensity and road emissions) in the cold start period $(t=300 \mathrm{~s})$. Finally, there were determined the shares of $\mathrm{CO}, \mathrm{CO}_{2}, \mathrm{NO}_{\mathrm{x}}$ and $\mathrm{PN}$ emissions in urban part and in the entire RDE test; during the cold start at $8^{\circ} \mathrm{C}$ and $25^{\circ} \mathrm{C}$ (Table 2).

The reduction of the ambient temperature (from $25^{\circ} \mathrm{C}$ to $8^{\circ} \mathrm{C}$ ) during the cold start (in the considered period of
$300 \mathrm{~s}$ ) results in an increase of all exhaust compounds, except $\mathrm{NO}_{\mathrm{x}}$. The share of this compound is greater at the higher ambient temperature. This trend is caused by the combustion process in the engine and the formation of nitrogen oxides. Another reason is warming of exhaust after-treatment system. It is necessary to modify and improve exhaust after-treatment systems so that they fulfil their function at a lower operating temperature.

Table 2. Characteristics of the passenger car used in testing

\begin{tabular}{|l|c|c|c|c|}
\hline \multirow{2}{*}{} & \multicolumn{2}{|c|}{$\mathrm{T}_{\text {amb }}=8{ }^{\circ} \mathrm{C}$} & \multicolumn{2}{c|}{$\mathrm{T}_{\text {amb }}=25^{\circ} \mathrm{C}$} \\
\cline { 2 - 5 } & $\begin{array}{c}\text { Share in the } \\
\text { urban part }\end{array}$ & $\begin{array}{c}\text { Share in the } \\
\text { RDE test }\end{array}$ & $\begin{array}{c}\text { Share in the } \\
\text { urban part }\end{array}$ & $\begin{array}{c}\text { Share in the } \\
\text { RDE test }\end{array}$ \\
\hline $\mathrm{CO}$ & $26.0 \%$ & $10.8 \%$ & $10.7 \%$ & $4.63 \%$ \\
\hline $\mathrm{CO}_{2}$ & $11.6 \%$ & $3.40 \%$ & $9.80 \%$ & $3.40 \%$ \\
\hline $\mathrm{NO}_{\mathrm{x}}$ & $10.6 \%$ & $2.92 \%$ & $12.3 \%$ & $3.42 \%$ \\
\hline $\mathrm{PN}$ & $22.7 \%$ & $0.05 \%$ & $18.4 \%$ & $0.05 \%$ \\
\hline
\end{tabular}

\section{Acknowledgements}

This study was funded by Projects 05/52/DSPB/1278

\section{Nomenclature}

$\mathrm{CO}$

GPS Global Positioning Signal

$\mathrm{NO}_{\mathrm{x}} \quad$ nitrogen oxides
PEMS Portable Emissions Measurement System

PN particle number

RDE Real Driving Emissions

WLTC Worlwide Harmonized Light Vehicles Test Cycle

\section{Bibliography}

[1] CHEN, Y., BORKEN-KLEEFELD, J. Real-driving emissions from cars and light commercial vehicles - Results from 13 years remote sensing at Zurich/CH. Atmospheric Environment. 2014, 88, 157-164.

https://doi.org/10.1016/j.atmosenv.2014.01.040

[2] Commission Regulation (EU) 2014 No 133/2014 of 31 January 2014 amending, for the purposes of adapting to technical progress as regards emission limits, Directive 2007/46/EC of the European Parliament and of the Council, Regulation (EC) No 595/2009 of the European Parliament and of the Council and Commission Regulation (EU) No $582 / 2011$

[3] Commission Regulation (EU) 2014 No 136/2014 of 11 February 2014 amending Directive 2007/46/EC of the European Parliament and of the Council, Commission Regulation (EC) No 692/2008 as regards emissions from light passenger and commercial vehicles (Euro 5 and Euro 6) and Commission Regulation (EU) No 582/2011 as regards emissions from heavy duty vehicles (Euro VI).

[4] Commission Regulation (EU) 2014 No 627/2014 of 12 June 2014 amending Regulation (EU) No582/2011 for the purposes of adapting it to technical progress as regards particulate matter monitoring by the on-board diagnostic system.

[5] Commission Regulation (EU) 2016 No 2016/1718 of 20 September 2016 amending Regulation (EU) No 582/2011 with respect to emissions from heavy-duty vehicles as regards the provisions on testing by means of portable emission measurement systems (PEMS) and the procedure for the testing of the durability of replacement pollution control devices.

[6] Commission Regulation (EU) 2017 No 2017/1347 of 13 July 2017 correcting Directive 2007/46/EC of the European Parliament and of the Council, Commission Regulation (EU) No 582/2011 and Commission Regulation (EU) 2017/1151 supplementing Regulation (EC) No 715/2007 of

the European Parliament and of the Council on typeapproval of motor vehicles with respect to emissions from light passenger and commercial vehicles (Euro 5 and Euro 6 ) and on access to vehicle repair and maintenance information, amending Directive 2007/46/EC of the European Parliament and of the Council, Commission Regulation (EC) No 692/2008 and Commission Regulation (EU) No 1230/2012 and repealing Regulation (EC) No 692/2008.

[7] DAHAM, B., LI, H., ANDREWS, G. et al. Comparison of real world emissions in urban driving for Euro 1-4 vehicles using a PEMS. SAE Technical Paper 2009-01-0941. 2009. https://doi.org/10.4271/2009-01-0941

[8] DIMARATOS, A., TOUMASATOS, Z., DOULGERIS, S. et al. Assessment of $\mathrm{CO}_{2}$ and $\mathrm{NO}_{\mathrm{x}}$ emissions of one diesel and one bi-fuel gasoline/CNG Euro 6 vehicles during realworld driving and laboratory testing. Frontiers in Mechanical Engineering. 2019, 3.

https://doi.org/10.3389/fmech.2019.00062

[9] DONATEO, T., GIOVINAZZI, M. Some repeatability and reproducibility issues in real driving emission tests. $S A E$ Technical Paper 2018-01-5020. 2018. https://doi.org/10.4271/2018-01-5020

[10] FARIA, M., VARELlA, R., DUARTE, G. et al. Engine cold start analysis using naturalistic driving data: City level impacts on local pollutants emissions and energy consumption. Science of The Total Environment. 2018, 630, 544-559. https://doi.org/10.1016/j.scitotenv.2018.02.232

[11] FRANCO, V., ZACHAROPOULOU, T., HAMMER, J. et al. Evaluation of exhaust emissions from three diesel-hybrid cars and simulation of after-treatment systems for ultralow real-world $\mathrm{NO}_{\mathrm{x}}$ emissions. Environmental Science \& Technology. 2016, 50, 13151-13159.

https://doi.org/10.1021/acs.est.6b03585

[12] GALLUS, J., KIRCHNER, U., VOGT, R. et al. Impact of driving style and road grade on gaseous exhaust emissions 
of passenger vehicles measured by a portable emission measurement system (PEMS). Transportation Research Part D: Transport and Environment. 2017, 52, 215-226. https://doi.org/10.1016/j.trd.2017.03.011

[13] GIS, M. Assessment of exhaust emissions from vehicles in real traffic conditions. IOP Conference Series: Earth and Environmental Science. 2019, 214, 012035. https://doi.org/10.1088/1755-1315/214/1/012035

[14] HOOFTMAN, N. A review of the European passenger car regulations - real driving emissions vs local air quality. Renewable and Sustainable Energy Reviews. 2018, 86, 1-21. https://doi.org/10.1016/j.rser.2018.01.012

[15] JOHNSON, T., JOSHI, A. Review of vehicle engine efficiency and emissions. SAE International Journal of Engines. 2018, 11(6), 1307-1330. https://doi.org/10.2307/26649163

[16] KRZESZOWIAK, J., STEFANOW, D., PAWLAS, K. The impact of particulate matter $(\mathrm{PM})$ and nitric oxides $\left(\mathrm{NO}_{\mathrm{x}}\right)$ on human health and an analysis of selected sources accounting for their emission in Poland. Medycyna ŚrodowiskowaEnvironmental Medicine. 2016, 19(3), 7-15. https://doi.org/10.19243/2016301

[17] LAIRENLAKPAM, R., JAIN, A., GUPTA, P. et al. Effect of Real world driving and different drive modes on vehicle emissions and fuel consumption. SAE Technical Paper 2018-01-5017. 2018. https://doi.org/10.4271/2018-01-5017

[18] LEMAN, A.M., RAHMAN, F., JAJULI, A. et al. Emission treatment towards cold start and back pressure in internal combustion engine against performance of catalytic converter: A review. MATEC Web of Conferences. 2017, 87, 02021. https://doi.org/10.1051/matecconf/20178702021

[19] MCCAFFERY, C., ZHU, H., LI, C. et al. On-road gaseous and particulate emissions from GDI vehicles with and without gasoline particulate filters (GPFs) using portable emissions measurement systems (PEMS). Science of the Total Environment. 2020, 710, 136366.

https://doi.org/10.1016/j.scitotenv.2019.136366

[20] MERKISZ, J., PIELECHA, J., GIS, W. Comparison of vehicle emission factors in NEDC cycle and road test. Proceedings of The Ninth Asia-Pacific International Symposium on Combustion and Energy Utilization. 2008, 477-482.

[21] MERKISZ, J., PIELECHA, J., GIS W. On-road testing and characterization of the exhaust emissions of light-duty vehicles. Sustainable Development and Planning. 2009, 12(120), 439-449.

[22] MERKISZ, J., PIELECHA, J., RADZIMIRSKI, S. New trends in emission control in the European Union. Springer Tracts on Transportation and Traffic. 2014, 4, 67-90. https://doi.org/10.1007/978-3-319-02705-0

[23] NOWAK, M., PIELECHA, J. Comparison of exhaust emission on the basis of Real Driving Emissions measurements and simulation. MATEC Web of Conferences. 2017, 118, 00026. https://doi.org/10.1051/matecconf/201711800026

[24] PRATI, M., MECCARIELLO, G., DELLA RAGIONE, L. et al. Real driving emissions of a light-duty vehicle in Na-

Karolina Kurtyka, MEng. - Faculty of Civil and Transport Engineering, Poznan University of Technology.

e-mail: karolina.t.kurtyka@doctorate.put.poznan.pl ples. Influence of Road Grade. SAE Technical Paper 201524-2509. 2015. https://doi.org/10.4271/2015-24-2509

[25] RDE Act 12016 Commission Regulation (EU) 2016/427 of 10 March 2016 amending Regulation (EC) No 692/2008 as regards emissions from light passenger and commercial vehicles (Euro 6).

[26] RDE Act 22016 Commission Regulation (EU) 2016/646 of 20 April 2016 amending Regulation (EC) No 692/2008 as regards emissions from light passenger and commercial vehicles (Euro 6).

[27] RDE Act 32017 Commission Regulation (EU) 2017/1154 of 7 June 2017 amending Regulation (EU) 2017/1151 supplementing Regulation (EC) No 715/2007 of the European Parliament and of the Council on type-approval of motor vehicles with respect to emissions from light passenger and commercial vehicles (Euro 5 and Euro 6) and on access to vehicle repair and maintenance information, amending Directive 2007/46/EC of the European Parliament and of the Council, Commission Regulation (EC) No 692/2008 and Commission Regulation (EU) No 1230/2012 and repealing Regulation (EC) No 692/2008 and Directive 2007/46/EC of the European Parliament and of the Council as regards real-driving emissions from light passenger and commercial vehicles (Euro 6).

[28] RDE Act 42018 Commission Regulation (EU) 2018/1832 of 5 November 2018 amending Directive 2007/46/EC of the European Parliament and of the Council, Commission Regulation (EC) No 692/2008 and Commission Regulation (EU) 2017/1151 for the purpose of improving the emission type approval tests and procedures for light passenger and commercial vehicles, including those for in-service conformity and real-driving emissions and introducing devices for monitoring the consumption of fuel and electric energy.

[29] SUARES-BERTOA, R., ASTORGA, C. Impact of cold temperature on Euro 6 passenger car emissions. Environmental Pollution. 2018, 234, 318-329.

https://doi.org/10.1016/j.envpol.2017.10.096

[30] SUAREZ-BERTOA, R., VALVERDE, V., CLAIROTTE, $M$. et al. On-road emissions of passenger cars beyond the boundary conditions of the Real-Driving Emissions Test. Environmental Research. 2019, 176. https://doi.org/10.1016/j.envres.2019.108572

[31] VARELLA, R., DUARTE, G., BAPTISTA, P. et al. Analysis of the influence of outdoor temperature in vehicle coldstart operation following EU real driving emission test procedure. SAE International Journal of Commercial Vehicles. 2017, 10(2), 596-697. https://doi.org/10.4271/2017-24-0140

[32] VARELlA, R., DUARTE, G., BAPTISTA, P. et al. Comparison of data analysis methods for European Real Driving Emissions Regulation. SAE Technical Paper 2017-01-0997. 2017. https://doi.org/10.4271/2017-01-0997

[33] WILLIAMS, R., ANDERSSON, J., HAMJE, H. et al. Impact of demanding low temperature urban operation on the real driving emissions performance of three European diesel passenger cars. SAE Technical Paper 2018-01-1819. 2018. https://doi.org/10.4271/2018-01-1819

Prof. Jacek Pielecha, DSc., DEng. - Faculty of Civil and Transport Engineering, Poznan University of Technology.

e-mail: jacek.pielecha@put.poznan.pl

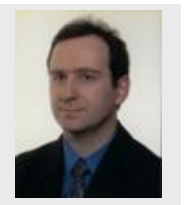

